\title{
FROM ECONOMIC TO SOCIOECONOMIC DEVELOPMENT
}

\author{
Jan Tinbergen \\ Netherlands School of Economics, the Hague, the Netherlands
}

\section{The "Economicist" Concept of Development}

There is no doubt that human life in the more prosperous countries has changed very rapidly during the last few centuries. The availability of many forms of comfort has increased at a high rate. To a considerable extent, the forces behind this change are increased scientific and technological knowledge manifesting itself in the large numbers of new goods, in improvement in their qualities, and in a continuous change of production processes using increasingly ingenious and increasingly complicated means. A very considerable portion of these innovations have been created by individual minds and by individual acts, in which the individual was guided by personal interest and personal gain. Inventors, engineers, managers, and owners of means of production were moved largely by such personal motives. Scientists' and technicians' work was for quite some time one-man work, and so was employers' activity. To be sure, they cooperated in groups of increasing size, but for a long time this cooperation was based on contracts that could be easily discontinued. And even though groupings of individuals of increasing size came to play their role, for the period under review the process of our society's development was described as a process in which each person pursued his own interest. Attempts were even made to prove that such an attitude was conducive to the maximum of satisfaction for all and was creating the "best of all conceivable worlds." This was typically the attitude of economic science, represented by its "father," Adam Smith, and continued to be the approach adhered to by economists for a considerable portion of the 20 th century. The political representatives of the élite in power in most modern countries continued even longer to believe that individualism had to be the basis of economic development, stressing the role of individual responsibility as an invigorating force fostering further development of human society. A strong belief in private enterprise and economic freedom prevailed, which were thought to take care automatically of everybody's interest, providing employment and a living to all, with incomes reflecting social justice: everyone got from society the equivalent of what he was giving to it. We will call this view the "economicist" concept of development. For a long time, this view was held especially in the United States.

\section{Reactions IN EUROPE}

The economicist view was held in Europe also, but reactions to it came earlier than in the United States. The first reactions came as early as 1850 , especially on the part of Karl Marx and his followers. For a considerable period their influence was limited, however, to the workers' world, where they gave rise to the creation-or the reorientation-of trade unions and of 
political parties with only slight influence. Some influence penetrated into parliaments, however, and in the second half of the 19th century a beginning was made with social legislation, tending to interfere with complete economic freedom in favor of some of the very weakest social groups, such as children, and some affected by accidents or professional illnesses. In the more advanced countries, the income tax was introduced. Socialist ideas penetrated into the working class to the extent that the Pope was induced to launch the encyclical De rerum novarum (1891). One of the features of the Roman Catholic approach of these days was to recognize the right of every family to a minimum of decent living.

More important changes took place during or immediately after World War I, which led to the two Russian revolutions, of which the second brought the nondemocratic wing of the socialist movement to power in Russia and at the same time accentuated the split in that movement between the democratic and the nondemocratic wings, later also known as the social democrats and the communists. The Soviet Union established a society that did away almost completely with economic freedom and to a large extent with private enterprise. In the most advanced Western European countries, the public sector, social legislation, tax legislation, and some other types of restriction on private enterprise and economic freedom were pushed, leading to the form of integrated socioeconomic development later known as the welfare state. One of the limitations observed was that most workers, or even trade union leaders, were not particularly interested in what is nowadays called "participation" (in those days "industrial democracy" or "codetermination").

\section{Reactions in the United States}

As already stated, in the United States the philosophy of free enterprise was adhered to for a longer period. It was only in the Great Depression, after 1929 , that the belief in the automatic cure of all evils by free enterprise received a bad shock, simultaneously with another shock in Europe. In the United States, the New Deal brought a number of limitations to freedom and introduced social legislation and other forms of government intervention at a scale until then unknown. In some respects the United States went further even than a number of European nations. This was partly due to its higher average level of income, which permits some types of interference to be stronger; thus, the ratio of direct to indirect taxes is higher in the United States than in most European countries, and capital gains taxes do not exist in many European countries.

The Great Depression also brought the recognition of the necessity to regulate untable markets, especially numerous in agriculture, and the need of an anticyclical fiscal policy. Elements of planning were introduced, and not only in the public sector. On the contrary, planning had its greatest victories in big business.

The Second World War reinforced the understanding for the necessity of government guidance, at least during emergencies, and developed several techniques of intervention. Some type of government planning, whether of the rather penetrating French type or the much looser Anglo-Saxon type (Council of Economic Advisers in the United States, Cabinet Offices and, later, "Neddy" in Britain) entered the scene in almost all Western countries. 


\section{BACK TO ECONOMICISM}

The end of World War II brought some reinforcement of economicism, however. In the United States, the untimely dissolution of the Office of Price Administration-leading to world inflation-was one example; in Western Germany, as a reaction to Hitlerism, a revival of slightly old-fashioned ideas under the beautiful name of "social market economy" brought back some economicist attitudes, which, to be sure, helped to rebuild the German economy (the "Wirtschaftswunder"). Even so, anticyclical policies continued and were remarkably successful; social insurance was expanded further, and for quite some time reconstruction in Western Europe required some forms of intervention, including macroeconomic planning imposed by the Marshall Plan! After the reconstruction period was over, by 1960 or thereabouts, there was an increased interest for some economicist elements, strengthened also by some difficulties experienced by Eastern Europe, which had been brought under Soviet domination after World War II. With increasingly complicated production processes and higher standards of living, Eastern Europe needed another mix of planning and freedom, or, at least, a larger number of levels of decision making. This was brought by some of the well-known reforms, exploited by free-enterprise propaganda. A number of American authors introduced the concept of "market socialism," without stressing sufficiently that for many activities, even in the West, markets must be regulated and that a considerable sector still requires more rather than less planning. This is true in particular for activities causing ecological disequilibria (air and water pollution, external effects of drugs, etc.). It cannot be denied, however, that around the '60s there was a tendency again to forget about a number of "social" issues. We will discuss their nature and their role in the subsequent section of this paper.

\section{Nature of Social Elements}

Scientific interest in "social elements" in human life has developed, as usual, much later than the intuitive interest shown by society. While economics faculties were given independence from law faculties around the '20s in the more advanced countries, sociology or social science faculties were a much later development. While the League of Nations' Secretariat had a Financial Section and Economic Intelligence Service next to a number of political and technical units, it is only in the United Nations' Secretariat that, even though the International Labour Organization was the oldest "specialized agency," the need was felt to have a Department of Social Affairs separate from the Department of Economic Affairs. As late as 1964, the United Nations Research Institute for Social Development took its modest place in the United Nations family of institutions, reflecting an increased pressure from the Social Commission (now Commission for Social Development) to introduce "social elements" into development planning. This is not to say that many social issues had not already been studied scientifically long before, but it illustrates the lag in comparison with the study of economic problems.

There are three definitions of what constitute "social aspects of development." The oldest and, in my opinion, best definition is all measures to correct complete economic freedom. In this sense we have seen the establishment of 
Ministries of Social Affairs and similar institutions in order to moderate laissez faire. The second definition has come into use, it seems, in an attempt to define some fields or sectors in which the activities of a social character were concentrated. It is a summing up, as of health, housing, education, nutrition, community development, and perhaps a few other matters. My rejection of such a definition is based on the fact that not all activities directed at better health, better housing, education, etc., are in fact meant to be included. Large portions of these activities are carried out by individuals acting in their own interest, as under laissez faire. It is only to the extent that the results of income distribution under economic freedom have to be corrected that measures on behalf of weak groups are taken in these fields, and this means that the first definition of social aspects is more satisfactory. A third attempt to define social, as distinct from economic, aspects identifies social aspects with the ultimate aims of development and economic aspects with the means applied to attain the aims. While this structure of a development policy, that is, the distinction between aims and means, is very important, we have already got terms to make the distinction ever since the Swedish school started giving attention to it, ${ }^{a}$ and I see no need to change the terms chosen. This is why I prefer the oldest definition. I should add that there is perhaps no need at all to use the word social in contradistinction to economic. We may simply speak about socioeconomic development, thus using a term introduced long ago by Cassel ${ }^{b}$ simply to indicate the difference between the economics of society and business or enterprise economics.

In any case, it has long been admitted that the aims of development should be the maximum welfare of the population as a whole over a long period and that the elements of welfare are all those things that make people happy. Among them are things of a material nature and of a nonmaterial nature and things pertaining to personal needs as well as to social needs-that is, needs of groups or needs springing from a comparison between one individual and others. The length of the period is the most difficult aspect of defining welfare; elements involved here are that longer-term interests of one individual should not be forgotten vis-à-vis short-term interests, but also that the distribution between generations should be observed. ${ }^{c}$

Although the economicist view does imply the care for elements of an individual character, the integrated socioeconomic view, while not forgetting the importance of personal incentives and initiatives, brings in the elements of comparison and hence of distribution. For the satisfaction of the poorer groups in any society, the distribution of welfare among individuals and groups is a vital element. It is insufficient to see to it that, as Rerum novarum put it, a minimum of decent life is attained, or, rather, this formula is empty to the extent that what is considered decent depends on what others have. Marx

- Although the concepts have been used earlier by his compatriots the clearest introduction of the aims and means of economic policy (in his case fiscal policy) can be found with B. Hansen in his Finanspolitikens Ekonomiska Teori (Stockholm 1955); cf. also E. Lindahl, Studies in the Theory of Money and Capital, London 1939, p. 22.

${ }^{b}$ G. Cassel called his well-known textbook on economics "Theoretische Sozialökonomie".

'M. Inagaki, The Theory of Optimal Economic Growth: A Contribution, diss. Rotterdam (to be published by North Holland) made a very remarkable contribution to exactly this aspect of the problem. 
spoke of a "customary standard" to establish what people think is decent. What really matters is the distribution of welfare (or, as the closest proxy, income) and not the absolute level or even the rate of improvement, although both of the latter have some relevance, especially in the short run. The following evidence may be quoted in support of my thesis.

1. Already within the world of labor it is well known that, upon appraising a wage offer, workers pay considerable attention to the ratio of that wage to wages of others. As a matter of experience, wages in one industry are kept in line with those in some standard industry, especiaily in the metal-working industry.

2. More generally, there is the well-known desire not to differ too much from others, as illustrated by the phrases "keeping up with the Joneses" and "conspicuous consumption" as factors of discontent among those not able to consume as much as the standard consumption pattern.

3. As an illustration we see that in recent years all discontent about society shows up in demands for wage increase far surpassing the average rate of increase in income per capita. If workers were satisfied that the present distribution of income is "correct," they would not ask for so much more; but they feel they are disadvantaged.

4. Accordingly, public opinion polls reflect more dissatisfaction with existing income distribution the lower a group's income is.

In conclusion, I want to state that what has been overlooked by the economicist view is primarily the widespread feeling that income distribution is unsatisfactory, not only under laissez faire, but even in Western Europe's mixed system " and Eastern Europe's centrally planned system. On the other hand, there remains a hard core of truth in the economicist view, namely the need for personal incentives.

\section{ReCENT Blows to ECONOMICISM}

During the last five years or so, additional blows have been given to purely economicist thinking, on both sides of the Atlantic. In Western Europe, the postwar innovation processes had come to an end around 1960, and there is an increasing feeling that improvements in income distribution have also stopped. Moreover, the desire for more participation, which was not widespread in the '20s, has become a new dimension in the thinking not only of students but also of groups of employees. Although in different forms, some of these desires have also come to the fore in Eastern Europe. In some respects the Yugoslav development of workers' councils has attracted much interest. Yet, for a majority of employees, it is probably still income distribution that interests them most. The difficulty surrounding the demand for added income is that it is manifested by a demand for instruments that are not, according to economic analysis, the most appropriate ones. The demands are for higher wages, whereas the instruments that may do the job are to be found in tax structures and education policies.

"In Sweden, the Socialist Party and the Trade Union Central Organization, published a report, "Jämlikhet" (Equality), in 1969, which refiects the renewed interest in the subject. 
In the United States, similar desires have been expressed, but the problem has been complicated by its race aspect. In fact, what the United States is experiencing is a prelude to what the world at large will be facing soon: how to make up for the poor sections of society whose poverty is partly due to underprivileged positions and partly to the ensuing lag of participation in modern education and knowledge.

Two other features in recent discontent are worth mentioning. One is the tendency of some young people to despise the comfort created by technological progress. This could be a positive force for development if there were not another negative feature, a sort of modern anarchism, implying the untenable view that under the present technological circumstances one can first destroy the existing order and then start building a new one. The lack of understanding of present-day technology (in the widest sense, and including the technology of administration and government) inherent in this view is indicative of ignorance and emotion; our hopes must be for a more mature view on the means to change the society.

\section{The DeVeloping WoRld}

As stated in the preceding section, the world at large is the scene of similar feelings of discontent characteristic for the industrialized countries. The extreme poverty in which the masses of Asia, Africa, and Latin America are living is no longer accepted as an inevitable destiny. Thanks to the general development of science and technology, ideas are rapidly spreading to all corners of the earth and a confrontation of the poverty of the developing world with the relative prosperity of the developed world becomes more natural every day. The ideas are spreading that the growing gap in welfare is not a necessity and that the economicist view can no longer be the only basis for world economic relations.

Two features enormously complicate the problems of the Third World. One is that the attitudes of their populations are still influenced by cultural and societal elements that stand in the way of an efficient development of their economies. The cultural elements are those of a metaphysical origin as described, in their great variety, by cultural anthropologists. The societal elements are those of feudal stratification, with all the discrimination and taboos that go with it. The other complicating feature of the underdeveloped countries is the size of the problem, which has been so magnified by the population explosion, caused by the penetration of Western knowledge in the field of health before the other balancing elements of Western knowledge spread.

Even so, the essential problem of the developing countries is a repetition of the social problem in the developed world: the discovery of the neglect of what were called in the preceding sections the social aspects of development. Accordingly, we see a repetition of many discussions, first held about the Western social problem and now held about the world development problem. Most of the remedies found for at least a partial solution of the West's social problem can be recommended for the beginning of the solution of the world's development problem. I am not going to demonstrate this here; I have tried to do so elsewhere. The one aspect I want to highlight here is that again, as in Rerum novarum, we find those who maintain that it is sufficient that a minimum of decent living be organized for the masses of the poor. 


\section{What Lessons to BE LEARNED?}

What we have to learn from our own previous experience is that such a minimum of decent living, although desirable and necessary, will not be sufficient. What will really matter, in the long run, is the distribution of income, both within nations and among nations. Temporarily, a quick rate of improvement will satisfy the underprivileged; in the end their satisfaction will be determined by the ratio between their incomes and those of the privileged. While some differences in income are accepted as reasonable by everybody, a considerable portion of present income difference is not considered just. Differences due to explicit privileges-that is, discrimination-will not be accepted. Incomes obtained without effort will not be accepted either. There will be a tendency to ask equal incomes for people who are making equal efforts, even if these efforts do not produce the same results. This is what I think we are heading for. Economic science should try to find out how this can be attained without killing incentive. I think there are more possibilities than are usually considered among economists.

As already observed, the emphasis should be on tax systems and education activities, In regard to taxes, a shift from income taxes to wealth taxes is one of the avenues to follow. A given amount of wealth tax tends to contribute more to equality and to weaken incentives to work less than an equal amount of income tax. Because little is known about the precise reactions of the taxpayers, the shift should be undertaken step by step, so that the community can feel its way. In addition to a tax on financial or physical wealth, the possibility of taxing personal capabilities should be explored. Here we can expect only some modest first steps; thus, we may think of a special tax on persons with high academic scores. There are beginnings of such taxes in that scholarships have to be paid back at a higher annual rate by alumni who obtain good jobs than by those who obtain less good jobs.

In the field of education, the bottleneck has now been found to be the preschool education received in the family and the outside environment, and experiments are being made with special supplementary teaching to youngsters in the primary schools coming from underprivileged surroundings. If, along these lines, together with the already existing facilities for scholarships, the supply of trained and qualified manpower can be increased while the supply of less trained goes down, the bargaining position for income of the poorest strata will be improved and less inequality in wage and salary scales will result.e

In the international field, we should learn from experience first, something about the eventual aim of development cooperation. This aim should be to reduce the income gap between developed and developing countries. It will not be sufficient to aim at a "decent minimum" of income per capita, although for quite some time to come this aim will be sufficient. Actual living levels are so much below anything that could be called decent that both aims require the same action. Eventually, however, it will be distribution-that is, ratiosthat matters.

Much more important at present is, second, what should be undertaken in the short run.

The strategies needed in the international field have recently been described

- Some further elaboration of the ideas briefly set out here will be found in $J$. Tinbergen, "Development Strategy and Welfare Economics," Coexistence 6 (1969) p. 119. 
by the Pearson Report ${ }^{\mathrm{f}}$ and the Report of the United Nations Development Planning Committee.g It would be duplication to make a new attempt to indicate these strategies. Let me therefore briefly list only some of the most important recommendations of the latter committee, of which $I$ happened to serve as chairman.

For developing countries the most important recommendations are:

- to increase the country's savings by 0.5 percent of gross domestic product per annum;

- to carry through land reforms (that is, putting a ceiling on the amount of land owned by one family) or to introduce a progressive tax on land and some other elements of physical wealth which can be easily assessed;

- to eliminate privileges given to some social groups;

- to improve efficiency and cooperation within the government machine;

- to reorient education and methods of education to meet the need for technicians and entrepreneurs;

- to cooperate with neighboring countries to establish larger markets;

- to improve marketing of their export products.

For developed countries the most important recommendations are:

- to make available a financial flow to developing countries of one percent of gross national product;

- to ease conditions for public financial transfers, which should attain 0.75 percent of gross national product and, by 1975 , show an "aid content" of about 80 percent;

- to eliminate, in about five years, trade impediments to imports of semimanufactured and manufactured goods for developing countries;

- to conclude commodity agreements for unstable raw material markets;

- to spend, by 1980,5 percent of their research and development expenditures on problems relevant to developing countries and to transfer 0.05 percent of their gross national product to developing countries for direct support of science and technology.

For the United Nations system of agencies the recommendations are that the process of development policies and cooperation be regularly evaluated, at the following levels:

- the level of the single nation;

- the level of consortia or similar groups of countries cooperating with a developing country or a group of such countries;

- the regional level (corresponding with the Regional Commissions); and

- the world level.

\footnotetext{
' Partners in Development, Report of the Commission on International Development, Lester B. Pearson, chairman; New York, 1969.

- United Nations Development Planning Committee, Report of the Sixth Session (New York, 1969).
} 
While these evaluation processes are considered part of the administration of implementation, a group of independent experts has been asked to comment on the criteria used and the judgments passed. Their comments should be offered separately to the U.N. Economic and Social Council, where an annual discussion of progress and prospects should be held in preparation for the General Assembly. The importance of evaluation is its feedback on policies, and hence the contribution it can make to increase the efficiency of the operation. 